\title{
Sustainable Dyeing of Cellulosic Fabric with Reactive Violet H3R dye: Ultrasonic Assisted Improvement in Color Characteristic
}

\author{
Shahid Adeel ${ }^{1 *}$, Shumaila Kiran ${ }^{2}$, Maria Jannat ${ }^{2}$, Nimra Amin², Atya Hassan ${ }^{3}$, Muhammad Abdul \\ Qayyum ${ }^{4}$, Shahid Rehman Khan ${ }^{5}$ \\ ${ }^{1}$ Department of Chemistry, Government College University, Faisalabad-38000, Pakistan. \\ ${ }^{2}$ Department of Applied Chemistry, Government College University, Faisalabad-38000, Pakistan. \\ ${ }^{3}$ Department of Chemistry, Federal Urdu University of Arts, Science and Technology, Karachi, Pakistan. \\ ${ }^{4}$ Department of Chemistry, Division of Science \& Technology, University of Education, Lahore, Pakistan. \\ ${ }^{5}$ Applied Chemistry Research Centre PCSIR Laboratories Complex Ferozepur Road Lahore Pakistan.
}

*Corresponding author: Shahid Adeel, email shahidadeel@gcuf.edu.pk

Received February 26 ${ }^{\text {th }}, 2021$; Accepted April 27 ${ }^{\text {th }}, 2021$.

DOI: http://dx.doi.org/10.29356/jmcs.v65i3.1571

\begin{abstract}
Ultrasonic radiation (U. S.) is the sustainable and green technology which has transformed the domain of textiles. In the current study, ultrasonic treatment was employed to improve the reactive dyeing of cellulosic fabricby Violet H3R dye. For this purpose, U.S. treatment has been given to both solution \& fabric upto $50 \mathrm{~min}$. at 30 to $60{ }^{\circ} \mathrm{C}$. Promising results were obtained when cellulosic fabric was exposed to U.S. treatment at at $50{ }^{\circ} \mathrm{C}$ for a period of $30 \mathrm{~min}$. using dye bath of $55 \mathrm{~mL}$ having $7.5 \mathrm{pH}$. Glauber salt $(8 \mathrm{~g} / \mathrm{L})$ was employed as an exhausting agent at $60^{\circ} \mathrm{C}$ for $55 \mathrm{~min}$. Various shades of cotton fabric dyed at optimal conditions were obtained which showed that U.S. treatment has enhanced not only the colour strength but also the fastness rating from medium to outstanding. So, it can be concluded from the current study that U. S. treatment is not only good enough for improving the dyeing aptitude of Reactive Violet H3R dye, but it also uplifts the color features of dyed cotton fabric.

Keywords: Cellulosic fabric; FTIR; reactive violet H3R dye; SEM; ultrasonic irradiation.

Resumen. La radiación ultrasónica (U:S. por sus siglas en inglés) es la tecnología sostenible y verde que ha transformado el campo de los textiles. En este estudio, se llevó a cabo un tratamiento ultrasónico para mejorar el teñido reactivo de tela celulósica por el tinte Violet H3R. Para este propósito, se llevó a cabo un tratamiento con ultrasonido tanto a la solución como a la tela por hasta 60 minutos a 30 y $60^{\circ} \mathrm{C}$. Se obtuvieron resultados prometedores cuando la tela celulósica se expuso a un tratamiento con ultrasonido a $50^{\circ} \mathrm{C}$ durante un período de $30 \mathrm{~min}$, utilizando un baño de tinte $(\mathrm{de} 55 \mathrm{~mL})$ a $\mathrm{pH} 7,5$ de sal de Glauber $(8 \mathrm{~g} / \mathrm{L})$. Estas condiciones representan un sistema de agotamiento, aplicado a $60{ }^{\circ} \mathrm{C}$ durante $55 \mathrm{~min}$. Se obtuvieron varios tonos de tela de algodón teñidos en condiciones óptimas, lo que mostró que el tratamiento por ultrasonido mejora no solo la intensidad del color sino también el índice de solidez de media a sobresaliente. Por lo tanto, del estudio actual se puede concluir que el tratamiento con ultrasonido no solo es lo suficientemente bueno para mejorar la capacidad de teñido del tinte Reactive Violet H3R, sino que también realza las características del color de la tela de algodón teñida.
\end{abstract}

Palabras clave: Tejido celulósico; FTIR; colorante reactivo violeta H3R; SEM; irradiación ultrasónica. 


\section{Introduction}

Synthetic dyes being resistant to degradation by light, chemicals, and micro-organisms are important in the dyeing world [1-3]. Among these colorants, reactive dyes are the only class of synthetic dyes that covalently attach themselves to the substrate/fabric surface and become a part of it. Due to covalent bonding, these dyes having good fastness properties [4] are cost-effective, anionic and produce a wide range of bright shades [5] from pastel to darker, even black [6,7]. There is an aspiration in textile researchers to develop shades and fastness characteristics of various synthetic fabrics dyed by synthetic dyes through diverse techniques in the last decades. These techniques are also used to cure textile effluents [8-11].

Sonication is one of the widely used techniques, which is becoming more popular due to its efficiency, cost-effectiveness, and less energy consumption source in the textile dyeing [12, 13]. Ultrasound treatment (U.S.) not only improves the dyeing ability of colorants onto the substrate but also improves the dyeing behavior of fabrics via cavitation [14]. Cavitation is the growth and breakdown of microscopic bubbles capable of producing hot spots [15], which improves color yield [16], minimizes energy consumption, time, and chemicals [17]. It also created the mass transfer effect during dyeing which minimizes the effluent load [18].

Keeping in view the benefits of sonication, the current study has been undertaken to improve the reactive dyeing of cellulosic fabrics. Cellulose is finely oriented due to its highly crystalline nature and a long and rigid molecular structure [19-21]. Cellulose fiber is hydrophilic because it has a large number of hydroxyl groups present in its structure that readily form hydrogen bondswith water [22]. These hydroxyl groups and the chain conformation are responsible for the formation of several bonds with the dye and fabrics [23].

The aims of current studies are:

i) To uplift the dyeing aptitude of cellulosic fabric by Reactive Violet $\mathrm{H}_{3} \mathrm{R}$ dye through ultrasonic radiations (U.S.).

ii) To uplift the color characteristics of cellulosic fabric by Reactive Violet $\mathrm{H}_{3} \mathrm{R}$ dye.

\section{Experimental}

\section{Material and Methods Materials}

Reactive Violet H3R dye commonly known as Reactive Violet 1 (structure given below), has been provided by Sohaib Dyes Chemicals (Pvt.), Faisalabad, Pakistan. Mill Mercerized cellulosic fabric ready to dye was provided by Haris Dyes and Chemicals, Faisalabad, Pakistan. All other chemicals used were of analytical grade.<smiles>O=[N+]([O-])c1cc(Cl)c(O)c(/N=N/c2c([N+](=O)[O-])cc3cc([N+](=O)[O-])cc(Nc4nc(Cl)nc(Nc5cccc(S(=O)(=O)O)c5)n4)c3c2O)c1</smiles>

Fig. 1. Reactive Violet H3R dye (C.I. No. 182130). 


\section{Irradiation Process}

Both the cellulosic fabric and dye solution were exposed to ultrasonic radiations for 20-50 minutes at $30,40,50$, and $60{ }^{\circ} \mathrm{C}$, respectively using Ultrasonic Cleaner Bath (Rohs, $220 \mathrm{~V}, 40 \mathrm{kHz}$ ). For attaining maximum colour strength, all fabrics (irradiated (RC) and un-irradiated (NRC) were dyed by irradiated (RS) and un-irradiated reactive dye solution (NRS) at $60{ }^{\circ} \mathrm{C}$ for $45 \mathrm{~min}$. keeping fixed fabric to dye ratio (1:25). For comparison dyeing of fabric (Sim) with reactive dye olution has been done under U.S. treatment for 20-50 min. at $30,40,50$, and $60^{\circ} \mathrm{C}$, respectively.

\section{Optimization of Coloring Conditions}

To acquire maximum color uptake (K/S), the optimal fabric was dyed at various temperatures (40$90^{\circ} \mathrm{C}$ ) for $15,25,35,45,55$, and $65 \mathrm{~min}$. by using $20-80 \mathrm{~mL}$ of dye bath. To adjust the medium of the dye bath, dye solutions of various $\mathrm{pH}$ (7-11.5) were used. For achieving excellent exhaustion of dye bath having 2, 4, 6, 8 , and $10 \mathrm{~g} / \mathrm{L}$ of Table salt $(\mathrm{NaCl})$ and Glauber salt $\left(\mathrm{Na}_{2} \mathrm{SO}_{4}\right)$ were employed. For all parameters, the fabric to liquor ratio was kept constant i.e.1:25 [24].

\section{Evaluation of Quality Characteristics of Dyed Fabric}

SEM analysis was carried out to detect any variations at the cotton fabric surface before and after exposure to U.S. radiations, while FTIR analysis was performed to assess any alteration in the functional moiety of the cellulosic unit. The color strength of un-treated (NRC) and treated fabrics (RC) with reactive violet H3R dye was examined through the Kulbeka-Munk equation computed in spectra flash SF 600 with an illuminant of D65 $10^{\circ}$ observer [25]. To assess the effect of U.S. treatment on colorfastness, different ISO methods of light, washing and rubbing were assessed in the quality control Lab of Noor Fatima Fabrics, Faisalabad, Pakistan.

\section{Results and discussion}

The results given in Fig 2 a-d which show that ultrasonic treatment has given the promising effect on reactive dyeing of cellulosic fabric at various temperatures. At low temperature $\left(30^{\circ} \mathrm{C}\right)$, the ultrasonic treatment has not shown any effect, whereas untreated fabric (control) has given darker shades (Fig. 2 a). Upon rising the temperature of the ultrasonic bath up to $40^{\circ} \mathrm{C}$, no significant results have been obtained (Fig. 2 b). However, U.S. irradiation of cellulosic fabric has given good color strength at $50{ }^{\circ} \mathrm{C}$ for $30 \mathrm{~min}$. by employing unirradiated solution (Fig. 2 c). Hence, it is recommended that U.S. treatment to the cellulosic fabric at $50{ }^{\circ} \mathrm{C}$ for $30 \mathrm{~min}$. should be done for getting darker shades instead of irradiation of dyeing solution [25].

U.S. treatment has physically modified the fabric by scratching the fibers, which in turn, enhances the absorbability and uptake ability. On rising the U.S. time as well U.S. bath temperature, the dye molecules may disintegrate into small molecules through acoustic cavitation, which, in turn, has enhanced the mass transfer kinetics, to make the dyeing process well [26]. It has been found that smaller molecules sorb well instead of aggregates in form of the cluster onto modified fabric [27]. Upon washing, a lot of nonfixed dye was detached and a less K/S value was found. Hence it is found that U.S. irradiation for cellulosic fabric should be done instead of dye solution to get excellent results.

FTIR analysis shows that U.S. treatment has nothing to do with changes in the functional peaks of the cellulosic unit (Fig. 3(a-b)). However, SEM analysis for control and irradiated cellulosic fabric shows that there are some scratches at the surface of fibers (Fig. 4 a-b), which may have enhanced the uptake ability of a fabric to sorb more dye promisingly. Hence U.S. treatment has nothing to do with the chemical nature of fabric but modifies the fabric surface to improve its substantivity. 

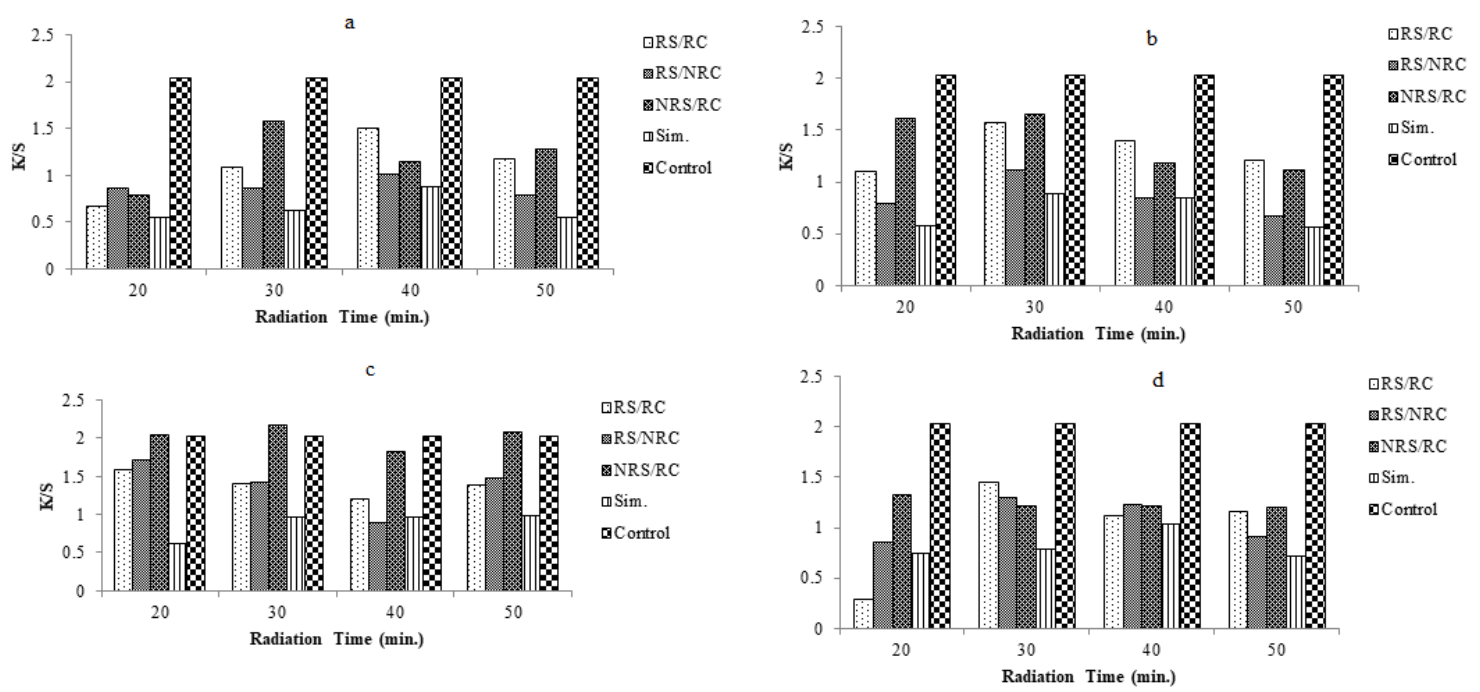

Fig. 2.U.S. treatment for both dye solution and cellulosic fabric at (a) $30{ }^{\circ} \mathrm{C} \mathrm{(b)} 40{ }^{\circ} \mathrm{C}$ (c) $50{ }^{\circ} \mathrm{C}$ (d) $60{ }^{\circ} \mathrm{C}$.

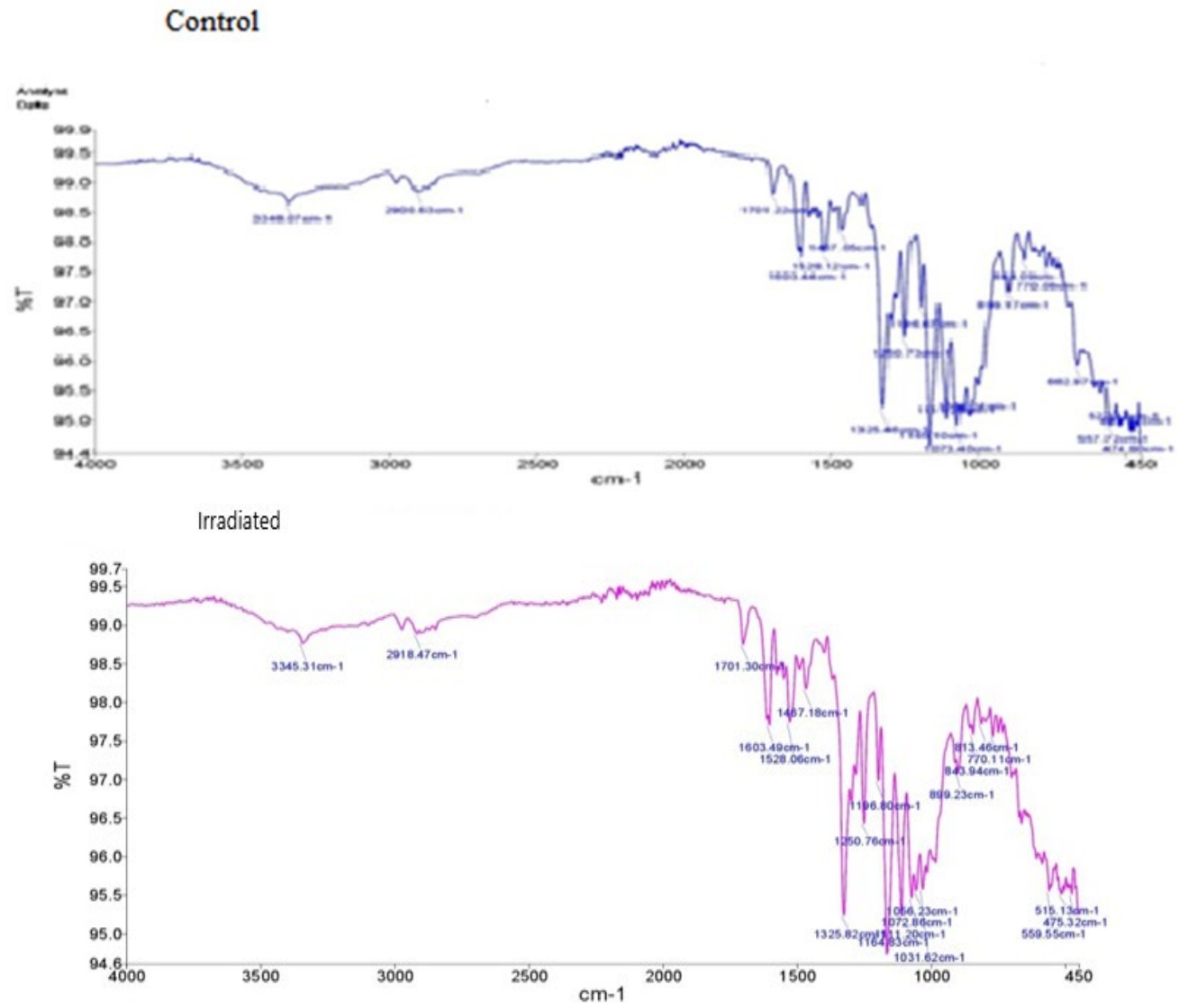

Fig. 3. (a) FTIR spectra of cellulosic fabric before ultrasonic treatment, (b) FTIR spectra of cellulosic fabric after ultrasonic treatment. 
a

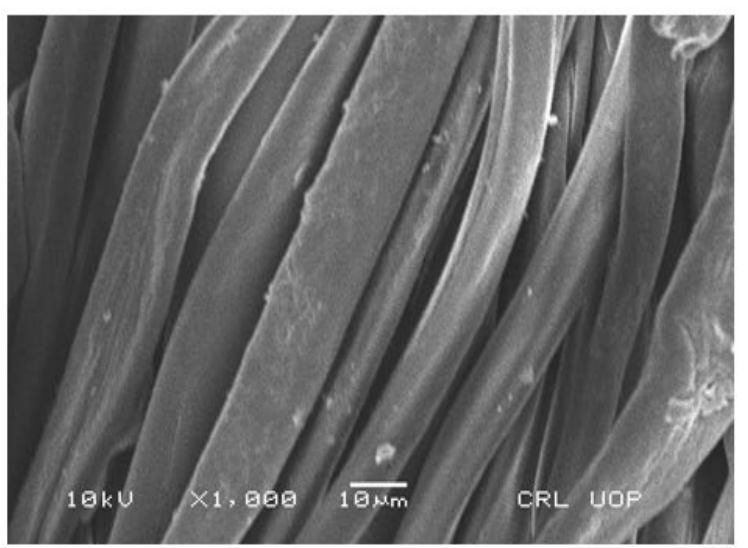

b

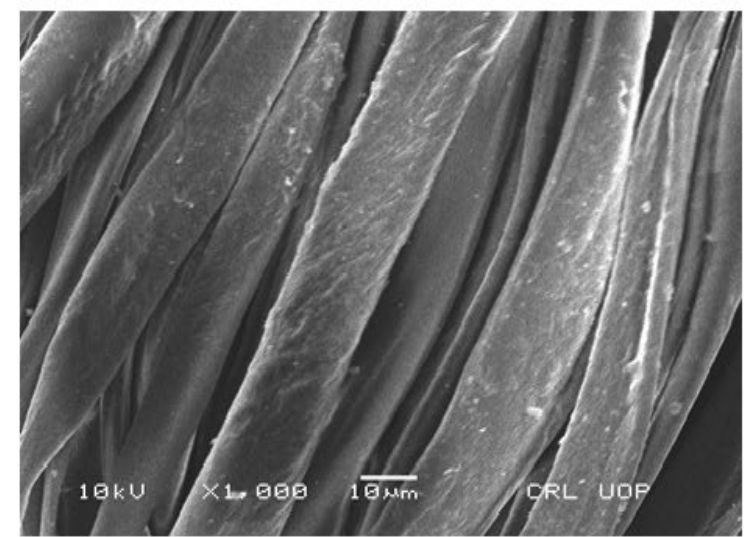

Fig. 4. SEM images of untreated (a) U.S. treated fabric (b).

Reactive dyeing of cellulosic fabric always requires the basic medium to make firm covalent interaction for getting desired results. This is because cellulosic fabric fixes the dye molecules at the $\mathrm{pH}$ range of 9-11, so for reactive dyes, dyeing has been started from neutral $\mathrm{pH}$, but up-to optimal level the uptake ability of fabric was enhanced, and maximum K/S was observed. Ultrasonic radiation has reduced the level of reactive dye bath from 11 to 9.5 thereby, increasing color charactersitics of fabrics dyed with Reactive Violet H3R solution. Above optimum $\mathrm{pH}$ (9.5), the dye bath may face hydrolysis process and too much alkaline medium may also weaken the fabric to grasp dye molecules [28]. The nonfixed dye was pulled out via washing with hot $\&$ cold-water treatment and less K/S value was obtained (Fig. 5 a). Hence under U.S. treatment for the dyeing of cellulosic fabric using Reactive Violet H3R dye bath at $\mathrm{pH} 9.5$ should be done to get excellent results.

Salt in reactive dyeing of cellulosic fabric is extensively used not only to decrease the rate of hydrolysis of dye but also to create the range of attractive force around the colorant, water, and fabric for getting maximum fixation and firm bonding [24]. The results displayed in Fig. $5 \mathrm{~b}$ show that $2 \mathrm{~g} / \mathrm{L}$ of Table salt $(\mathrm{NaCl})$ has given high color strength, whereas $8 \mathrm{~g} / \mathrm{L}$ of Glauber salt $\left(\mathrm{Na}_{2} \mathrm{SO}_{4}\right)$ has also given better color strength. But overall Glauber salt (T.S.) has given more color strength than that of table salt used. Hence, U.S. treatment to cellulosic fabric and Reactive Violet H3R dye solution has reduced the amount of salt used to achieve maximum exhaustion for deep shades. The volume of dye bath of specific $\mathrm{pH}$ incorporated with the optimum amount of salt always has given a good color appearance. The results displayed in Fig. $5 \mathrm{c}$ show that $55 \mathrm{~mL}$ of dye bath pH 7.5 has given good color strength after U.S. treatment for $50 \mathrm{~min}$.

Heating levels in reactive dyeing are very essential because significant diffusion can be achieved by raising the kinetic energy of the dyeing process at certain points. The results given in Fig. $5 \mathrm{~d}$ show that ultrasonic treatment of fabric (RC, $30 \mathrm{~min}$.) has given high color strength upon dyeing with non-irradiated solution (NRS). A low heating level does not raise the kinetic energy of the dye bath, whereas too much heating may cause either hydrolytic degradation of colorant or shift the equilibrium from dye bath to fabric. Upon finishing alot of unfixed dye remains at the surface of the fabric which is stripped while cold and hot washing [29-31]. The same has been observed, when contact time was raised slowly from 15-55 min. as shown in Fig. 6. For low contact time, the molecules mainly remain on the surface, whereas for high contact time (65 min.) may overheat the dyeing process, thereby causing desorption instead of sorption [32, 33]. Hence it is recommended that dyeing should be done for $55 \mathrm{~min}$. at $70{ }^{\circ} \mathrm{C}$ after U.S. treatment of dye bath. 

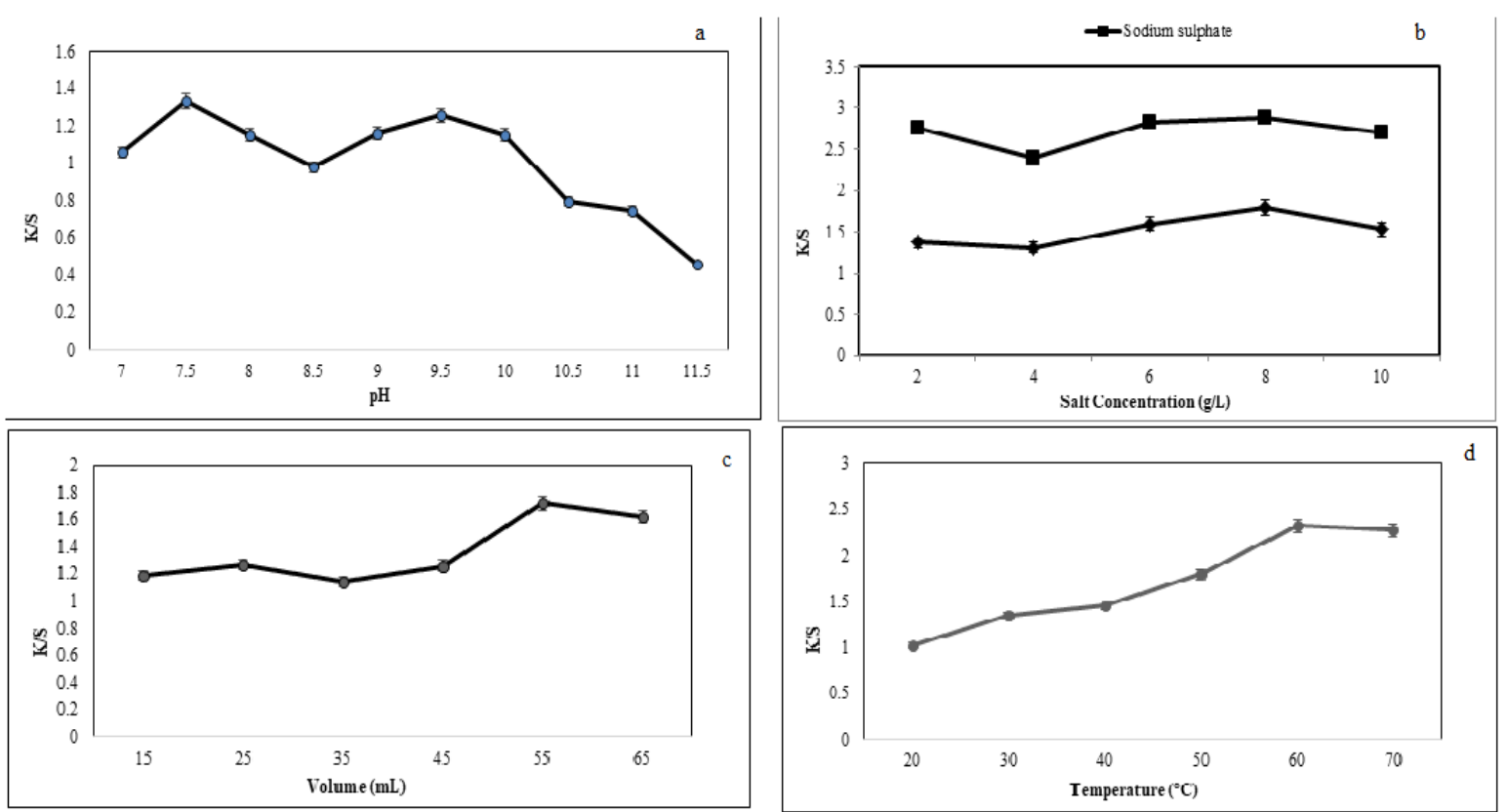

Fig. 5. Effect of $\mathrm{pH}$ (a) salt concentration (b) dye volume (c) heating level (d) on dyeing of cellulosic fabric using Reactive Violet H3R dye.

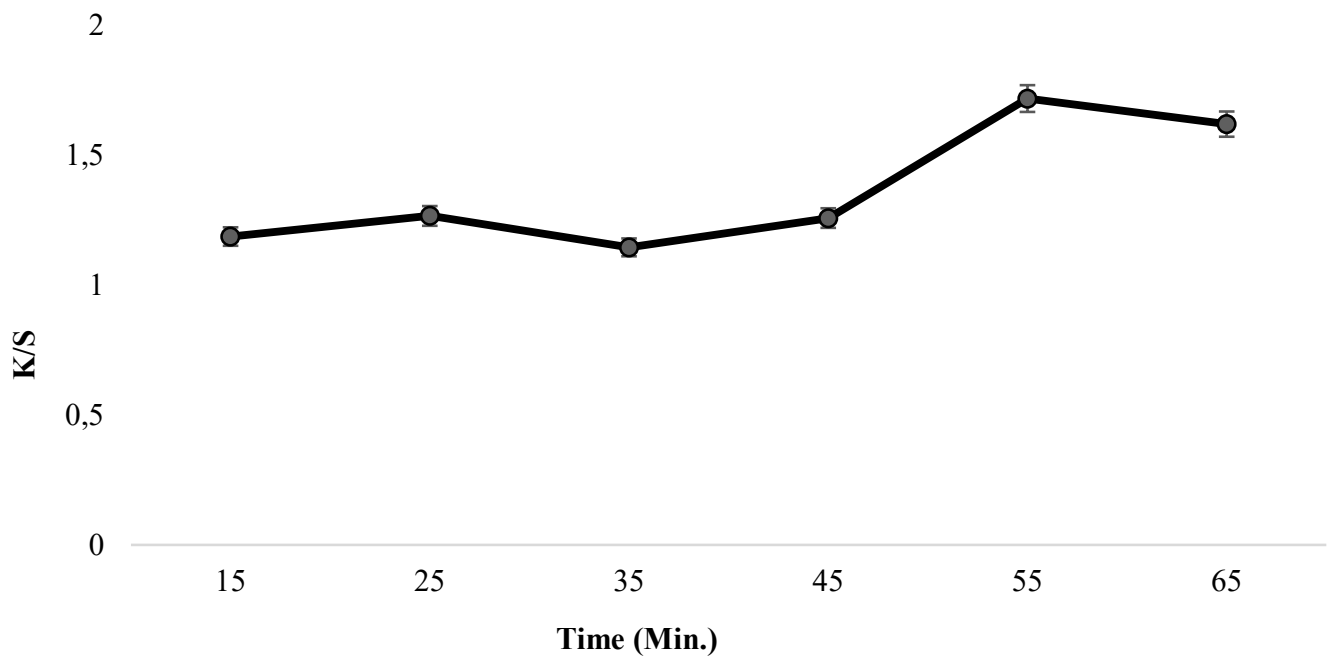

Fig. 6. Effect of contact level on dyeing of cellulosic fabric using Reactive Violet H3R dye.

The rating properties given in Table 1, show that the ultrasonic radiation of fabric (RS, $30 \mathrm{~min}$.), using Reactive Violet H3R dye solution has improved the rating from moderate to excellent. This good rating has been attributed to the nature of the dye, binding functional sites, and the modified surface of the fabric. Upon dyeing through firm covalent bonding, the dyed fabric resists in fading the color. The conjugation system, in the dye molecule and benzenoid structure present in Reactive Violet H3R dye using play their role when the 
fabrics are exposed to heat, light, and detergents, which in turn helps to improve the grading upon comparison at greyscale [34, 35]. Hence it is concluded that U.S. treatment has improved the rating of colorfastness properties of cellulosic fabric when treated for $30 \mathrm{~min}$. at $50{ }^{\circ} \mathrm{C}$ and dyed under optium conditions.

Table 1. Effect of ultrasonic treatment on color fastness properties of various shades of dyed fabric.

\begin{tabular}{|c|c|c|c|c|c|}
\hline \multirow{2}{*}{$\begin{array}{c}\text { Dye } \\
\text { Concentration }\end{array}$} & \multicolumn{2}{|c|}{ Rub Fastness } & \multicolumn{2}{|c|}{ Washing Fastness } & \multirow{2}{*}{$\begin{array}{c}\text { Light } \\
\text { Fastnes }\end{array}$} \\
\hline & Dry & Wet & $\begin{array}{c}\text { Color } \\
\text { Change }\end{array}$ & $\begin{array}{l}\text { Color } \\
\text { Stain }\end{array}$ & \\
\hline 0.5 & 3 & 3 & $4-5$ & $3-4$ & $4-5$ \\
\hline 1 & 4 & 4 & $4-5$ & $3-4$ & 4 \\
\hline 1.5 & $3-4$ & $3-4$ & $3-4$ & $4-5$ & $3-4$ \\
\hline 2 & $4-5$ & 4 & $3-4$ & 5 & $3-4$ \\
\hline 2.5 & 4 & $3-4$ & $3-4$ & $4-5$ & 4 \\
\hline
\end{tabular}

\section{Conclusion}

A sustainable approach in reactive dyeing of cellulosic fabric is one of the most observed and implemented tool to minimize the effluent load. Of these approaches, utilization of U.S. treatment has been welcomed in synthetic dyeing to make the process green and less polluted. In the current study, ultrasonic rays have been employed to enhance absorptivity of cellulosic fabric \& the dyeing behavior of Reactive Violet H3R dye. The results show that U.S. treatment for fabrics should be done at $50{ }^{\circ} \mathrm{C}$ for $30 \mathrm{~min}$. to get high color strength using untreated dye solution. Under mild conditions, the shades should be formed at $50{ }^{\circ} \mathrm{C}$ for $55 \mathrm{~min}$. using $55 \mathrm{~mL}$ dye bath of $7.5 \mathrm{pH}$ and to achieve maximum exhaustion, $8 \mathrm{~g} / \mathrm{L}$ of Glauber salt should be used. The reduction in dyeing time and salt concentration show that U.S. treatment is time-saver and labor-saving technique. It is concluded that U.S. treatment can successfully be implemented to uplift the dyeing aptitude of other related dyes onto natural and synthetic fabrics.

\section{Acknowledgments}

We are grateful to Higher Education Commission of Pakistan (HEC) for funding the project (No. 202724/NRPU/R\&D/ HEC/12/6828). We are also thankful to Mr. Zafar Iqbal Manger QA \& QC of Noor Fatima Fabrics (Pvt.) Limited, Faisalabad Pakistan and Mr. Muhammad Abbas Director Harris Dyes and Chemical (Pvt.) Limited, Faisalabad for providing the technical assistance and implementation of the work at industrial scale.

\section{References}

1. Gunes, Y.; Atav, R.; Namirti, O. Text. Res. J. 2012, 82, 994-1000. DOI: https://doi.org/10.1177\%2F0040517511429611

2. Saeed, Q.; Bhatti, I. A.; Zuber,M.; Nosheen, S.; Zia, M.A.; Abbas, M. Int. J. Bas. Appl. Sci. 2012, 2, 191-197.

3. Khatri, A.; Peerzada, M. H.; Mohsin, M.; White, M. J. Clean. Prod. 2015, 87, 50-57. DOI: https://doi.org/10.1016/j.jclepro.2014.09.017 
4. Rehman, A.; Iqbal, K.; Azam, F.; Safdar, F.; Ashraf, M.; Maqsood, H. S.; Basit, A. The J.Text. Inst. 2020. DOI: $10.1080 / 00405000.2020 .1805952$

5. Hassani, E.;Jabkhiro, K.; Kalnina, H.; Beakou, D.; Anouar, B. H. Appl. Clay Sci. 2019, 182, 105-246. DOI: $10.1016 /$ j.clay.2019.105246

6. Chinta, S.K.; Kumar, V. S. Int. J. Engin. Manag. Sci. 2013, 4, 308-312.

7. Lykidou, S.; Karanikas, E.; Nikolaidis, N.; Tsatsaroni, E. Text. Res. J. 2017, 87, 694-707. DOI: https://doi.org/10.1177\%2F0040517516636004

8. Kiran, S.; Ali, S.; Asgher, M.; Shahid, S. A. J.Env. Sci. Water Resour. 2012, 1, 267-275.

9. Rashid, A.; Nosheen, S.; Kiran, S.; Bhatti, H. N.; Kamal, S.; Shamim, F.; Akram, W.; Rafique, M. A. Oxid. Commun. 2016, 39, 1716-1726.

10. Kiran, S.; Adeel, S.; Nosheen, S.; Hassan, A.; Usman, M.; Rafique, M. A. Advanced Mater. Wastewater Treat. 2017, 29-49.

11. Adeel, S.; Rehman, F.; Ahmad, T.; Amin, N.; Iqbal, S. Z.; Zuber, M. Text. Sci. Cloth. Technol. 2020. DOI: http://doi-org-443.webvpn.fjmu.edu.cn/10.1007/978-981-15-3669-4_14

12. Udrescu, C.; Ferrero, F.; Periolatto, M. Ultra. Sonochem. 2014, 21,1477-1481.

13. Babar, A. A.; Bughio, N.; Peerzada, M. H.; Naveed, T.; Dayo, A. Q. Ultra. Sonochem. 2019, 58, 104611, ISSN 1350-4177. DOI: https://doi.org/10.1016/j.ultsonch.2019.05.028.

14. Sheikh, J.; Jagtap, P.S.; Teli, M. D. Fiber Polym. 2016, 17, 738-743. DOI: https://doi.org/10.1007/s12221-016-5031-0

15. Tissera, N. D.; Wijesena, R.N.; Silva, K. N. Ultra. Sonochem. 2016, 29, 270-278.

16. Larik, S. A.; Khatri, A.; Ali, S.; Kim, S. H. Ultra. Sonochem. 2015, 24, 178-183. DOI: https://doi.org/10.1016/j.ultsonch.2014.12.016

17. Merdan, N.; Akalin, M.; Kocak, D.; Usta, I. Ultra. 2004, 42, 165-168. DOI: https://doi.org/10.1016/j.ultras.2004.02.005

18. Ferrero, F.; Periolatto, M. Ultra. Sonochem. 2012, 19, 601-606. DOI:10.1016/j.ultsonch.2011.10.006

19.Zhang, Z.; Ma, Z.; Leng, Q.; Wang, Y. Int. J. Biol. Macromol. 2019, 140, 303-310. DOI: 10.1016/j.jibiomac.2019.08.049

20. Xie, K.; Gao, A.; Li, M.; Wang, X. Carb. Polym. 2014, 101, 666-670.

21.Li, M.; Gao, A.; Wu, L.; Fu, D.; Xie, K. Text. Res. J. 2017, 87, 2127-2132. DOI: https://doi.org/10.1177\%2F0040517516665256

22. Das, D.; Bakshi, S.; Bhattacharya, P. Cloth. Text. Res. J. 2016, 34, 196-206. DOI: https://doi.org/10.1177\%2F0887302X16652998

23. Hsieh, Y. L. Cotton: Science and Technol. 2007, 3-34. DOI: https://doi.org/2F10.1533/2F9781845692483.1.3

24. Adeel, S.; Kiran, S.; Gulzar, T.; Rehman, F.; Azeem, M.; Ahmad, Z.; Iqbal, Z. J. Nat. Fiber. 2017, 14, 658-665. DOI: https://doi.org/10.1080/15440478.2016.1266292

25. Merouani, S.; Ferkous, H.; Hamdaoui, O.; Rezgui, Y.; Guemini, M. Ultra. Sonochem. 2015, 22, 5158. DOI: http://dx.doi.org/10.1016/j.ultsonch.2014.07.015

26. Elapasery, M.; Abdel G. R. A.; Kamel, M. M.; Youssef, B.M.; Haggag, K. M. Egyptian J. Chem. 2017, $60,143-151$.

27. Mansour, H.F.; Heffernan, S. Clean Technol. Environ. 2011, 13, 207-213. DOI: https://doi.org/10.1007/S10098-010-0296-2

28. Ristic, N.; Ristic I. J. Engin. Fab. Fibe. 2012, 7, 113-121. DOI: https://doi.org/10.1177\%2F155892501200700408

29. McNeil, S.J.; McCall, R. A. Ultras. Sonochem, 2011, 18, 401-406. 
30. Gorgani, A. S.; Najafi, F.; Karami, Z. Carb.Polym. 2015, 131, 168-176. DOI: $10.1016 /$ j.carbpol.2015.04.031

31.Li, Y. V.; Malensek, N.; Sarkar, A.K.; Xiang, C. Cloth.Text. Res. J. 2016, 34, 223-234. DOI: https://doi.org/10.1177\%2F0887302X16647124

32. Abid, S.; Hussain, T.; Nazir, A.; Raza, Z. A.; Siddique, A.; Azeem, A.; Riaz, S. Cloth. Text. Res. J. 2018, 36, 119-132. DOI: https://doi.org/10.1177\%2F0887302X17747048

33. Syed, U.; Samad, A.; Ahmed, F. Mehran Uni. Res. J. Engn. Technol. 2013, 32, 329-338.

34. Ajmal, M.; Adeel, S.; Azeem, M.; Zuber, M.; Akhtar, N.; Iqbal, N. Ind. Crops Prod. 2014, 58, 188193. DOI: http://4/dx.doi.org/10.1016/j.indcrop.2014.04.026

35. Hossain, I.; Hossain, A.; Choudhury, I. A. The J. Text. Inst. 2016, 107, 154-164. DOI: https://doi.org/10.1080/00405000.2015.1018669 